Roth, W.-M. (2013). Toward a post-constructivist ethics in/of teaching and learning. Pedagogies: An International Journal, 8, 103-125.

\title{
Toward a post-constructivist ethics in/of teaching and learning
}

\section{Wolff-Michael Roth, Griffith University}

\begin{abstract}
Constructivist epistemologies focuses on ethics as a system of values in the mind - even when previously co-constructed in a social context - against which social agents compare the actions that they mentally plan before performing them. This approach is problematic, as it forces a wedge between thought and action, body and mind, universal and practical ethics, and thought and affect. Drawing on a fragment of a concrete classroom episode as an exemplary case, I develop and exemplify a post-constructivist discourse on ethics that centers on the dialogical relation of participants in conversation and that overcomes the problems of the constructivist approach. This practical ethics is consistent with the dialectical (dialogical) conception of the world-as-event. I conclude by suggesting that the Saying constitutes a dialectical/dialogical paradigm of a post-constructivist ethics.
\end{abstract}

Key words: ethics; Levinas; Bakhtin; praxis; responsibility; response; radical passivity; Other

We call forth, and are ourselves summoned by, the words of others. (Holquist, 1990, p. xliv)

[T] he summons is understood only through the response and in it. (Chrétien, 2007, p. 39)

One cannot Separate response from responsibility. (p. 3)

[T] he one has no sense other than the-one-for-the-other: the diachrony of responsibility constitutes the subjectivity of the subject. (Levinas, 1971, p. 45)

In education, ethics generally is considered through the lens of the agent - i.e., through the lens of (intentional) agency - even when authors recognize the mutual nature of the ethical commitment that interaction participants make to a joint project (e.g., conversation) (e.g., Radford \& Roth, 2011). The position is common to constructivist and post-structuralist positions alike, such as when teachers are said to "have the sole responsibility for the well-being of their students" (Czarnocha, 2008, p. 80) or "primary school mathematics is what primary teachers make happen" (Brown \& McNamara, 2011, p. 13). This approach of thinking ethics through the agency may be the case even for those who articulate a much more differentiated view, such as Noddings (e.g., 1984/2003), who articulate such alternatives as caring, a relational concept, in terms of agency (e.g., "[Women] define themselves in terms of caring and work their way through moral problems from the position of onecaring" [p. 8]). Not only are these considerations through the lens of agency, but also agents (students, teachers) are considered by and large in terms of their mental/conceptual frameworks and a pervasive regard for elusive "meanings" that 
exist only at a metaphysical level (Roth, 2012; Wittgenstein, 1953/1997). But the question of ethics is not just an issue of the (metaphysical) mind - which, Nietzsche (1954a) says, may be thorough and deep but is wrong nevertheless - but pertains to the whole person-in-situation (Bakhtin, 1993). Thus, the question of ethics in education is often quite abstract (Noddings, 1984/2003), such as when mathematics education is said to implement measures of mathematical knowledge (Walshaw \& Brown, 2011); and this kind of implementation has consequences that allow separating good from bad actions (Lundin, 2011).

The problem with the metaphysical approach to ethics in education - which focuses on the agent who takes responsibility before they act by implementing some abstract rule - has been pointed out in the context of mathematics education. Thus, for example, Walshaw and Brown "suggest that teachers who are invested in the common advantage of all," and thereby act according to the (Kantian) categorical imperative, "are developing ways of thinking and being in the classroom setting that may be perpetuating the marginalisation of (as in this example) an already disadvantaged class." This fact that teachers who aim at doing good actually worsen the situation derives from the fact that at their very bottom, all actions, practical or discursive, are illogical and unjust (Nietzsche, 1954a) because (explanatory) accounts of actions always follow situated actions (Suchman, 1987). It is at this abstract level of the imperative that we can speak about obligations, such as the one that attributed to (mathematics) education means "to seek to transform classroom arrangements that impeded the production of knowledge" (Walshaw \& Brown, 2011). Ethics, thereby, first is an issue of the mind, which makes up plans of actions consistent with or against ethical standards that are subsequently implemented. Walshaw and Brown (2011) quite correctly note that there is a need to connect emotion to enactivism (embodiment), a move that can be completed through the manner in which interaction participants affect each other. But the relation of ethics to the practical classroom actions that they mobilize for their argument requires considerable levels of abstraction.

The four introductory quotations, which in fact outline a form of argument, direct us towards and guide us along the way towards an ethics that does not first exist in a metaphysical world to be subsequently grounded in and made relevant to practical action. Rather, in interaction with others, we are summoned by the words of others, whereby we are already placed in an obligation to answer and answer for. Moreover, when we speak as part of a societal relation, the word is for the other, which places the speaker in an obligation to the listener, who, as shown in this paper, is also in a relation of obligation to the speaker. There is therefore a diachrony of responsibility, which makes for the very constitution of our subjectivity as the subjects in the relation.

The purpose of this paper is to show, on the one hand, how ethics is inherent in each and every act/deed precisely because it is a concrete act/deed with irreversible consequences in the world - thereby contrasting the reversibility of actions in the mind (pace J. Piaget) - and, on the other hand, the fact that there is a responsibility for the actions of the other. I ground this argument for a post- 
constructivist ${ }^{1}$ ethics in the work of three scholars in particular - Mikhail Bakhtin, Emmanuel Levinas, and Jean-Luis Chrétien - because they have laid a foundation for the active and passive nature of the question of ethics in the act of speaking. I begin, consistent with the praxis-situated nature of my argument, by presenting and analyzing an actual classroom event from a fourth-grade mathematics lesson and then proceed to making a more extended case for a post-constructivist approach to ethics in education.

\section{The ethics of praxis is the praxis of ethics}

In this section, I present a fragment from a classroom episode ${ }^{2}$ to show that students and teachers do not just take responsibility but that they always already find themselves in a relation of responsibility and that each participant is answerable for the other. In analyzing the fragment, I am interested in getting the perspectives of the participants in and on the conversation. This requires me to listen to next speaker in whose locution we find reflected not only the understanding of the preceding speaker but also its "social evaluation" (Bakhtine [Volochinov], 1977)..$^{3}$ In this sense, every act of speech is a response, even the solitary one, and therefore does not begin knowing and learning (Chrétien, 2007) as constructivists want to have it. Because we are interested here in ethics as it arises from the inner forces that move this conversation, we have to understand how the participants themselves hear each other rather than imposing our interpretation of what someone has said. Thus, for example, we may not say that one speaker asks a question unless the second speaker treats it as such in his/her turn. This methodical approach analytically implements the contention that "the nervous center of any utterance, any expression, is not interior but exterior: it is situated in the social milieu that surrounds the individual" (p. 134). The recipient of a locution co-authors and countersigns it, and is thus as important as the speaker to the development of the conversation (Derrida, 1988). To understand the conversation as social situation in a specific societal setting, we therefore do not need to figure out what is in the minds of speakers hidden from view - e.g., their "meanings" - but we need to follow the social milieu that surrounds and comprises our speakers. That is, we have to hear a speaker as the listeners in the situation have

\footnotetext{
${ }^{1}$ In the constructivist framework, the contents of mind or mental structures determine what individuals say. There is a causal relationship between intentions and speech. The (social, material) world is not just taken to be present but also made present again in some form in mind (i.e., the mental constructions of the individual). A post-constructivist position gives up the idea that the world is fully present in the consciousness of the actor; and it gives up the idea of the cause-effect relation between mind and speech.

2 The 229-line transcription of the entire 12-minute episode is available in the original French and in translation (Roth \& Radford, 2011). Minor modifications had to be made, because errors in the original transcription became evident and to appropriately bring into alignment actions and words. 3 The term locution is used here to denote a moment of the minimal unit of analysis, which, for conversation analysts and Bakhtinian scholars, is the turn pair. There are no implications as to the speech intentions or speech effects.
} 
heard him/her, which we do by attending to how these listeners make available their hearing to the speaker in their reply.

\section{Saying is summoning and questioning}

The fragment derives from a classroom episode in which the fourth-grade students are asked to model a story in which a girl begins with $\$ 3$ in her piggybank and adds to it $\$ 6$ every week. The students are to arrive at a generalized way for figuring out the total amount so that they can easily predict, without counting out, the amount of money in the piggybank when the number of weeks is very large (e.g., after 117 weeks). The video shows that Aurélie already has abandoned the task and, in apparent frustration, pounds her fist on the desk; and Mario signals that he has difficulties in understanding what he is to do. The fragment picks up after the teacher Jeannie completes an evaluation of an answer by repeating what Thérèse has said and by proffering the first turn to a possible question-answer sequence (turn 069). In this situation, the relation with and to the (generalized) Other, here the students at the group of desks, accomplishes itself in Jeannie's Saying, oriented toward and therefore addressing the children. Jeannie's locution, addressed to the students, constitutes a summons, for them to take a next turn, and in this turn to produce a reply to what she has said. She does not address the students in the way she would address the mathematics education professor in the room, or some other adult. Rather, she addresses them at what is their presupposed level of understanding - and thereby already has made an ethical commitment even though she might not have thought about her actions in this way. More importantly, the figure of question-response is subordinated to a more fundamental one of summons-response (Chrétien, 2007), this latter, as a fundamental form of the dialogical relation, being more complex than the former (Bakhtine, 1984). The question of addressing the children is more primordial than the solicitation of a specific answer, for the second is impossible if the first condition is not met.

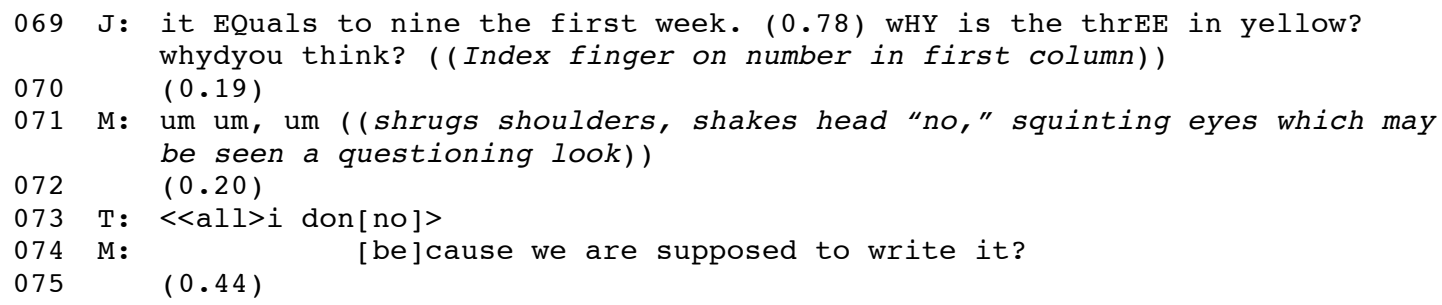

A summons is not a summons in and of itself. In praxis, it is a summons only if it is attended to and heard. To hear this summon, the students actually need to listen without knowing "what is coming at them" - which also could be an insult, a hurting remark, or a slur. The children are vulnerable because they cannot know what is coming at them in and with the Saying until it has arrived, that is, when they know what has been said, when the Said is available to them.

This next turn consists of interjections, which Mario accompanies by shaking his head as if signifying "no" (turn 71). Jeannie does not only produce a summons, in her saying she also exposes herself. In producing the locution "why is the three in 
yellow?" as a candidate question for a question-answer turn, Jeannie in fact exposes herself to possible failure. She does not nor can she know what will come on the part of the students, that is, the social evaluation that completes her locution that transforms the turn pair into an utterance (Bakhtine [Volochinov], 1977). Thérèse says "I donno," overlapped by Mario, who proffers a possible candidate for a question-answer sequence: "because we are supposed to write it?" (turn 74). That is, as intimated above, it is only through Mario's reply that we know the effect of Jeannie's locution. It is through his voice that we come to know what Mario has heard. In this situation, it is a candidate for an answer to a question. But whether it is a legitimate answer we cannot know until we hear Jeannie again, who makes available to us what she heard Mario say. That is, to reply is not only to provide an answer to but also to answer for, a responsibility for the other with regard to the particular hearing of the preceding locution, which completes a sequentially organized turn pair. It is a responsibility for an inherent and unavoidable irresponsibility that arises from the fact that there is an excess of consequences of the action over any intent (Nietzsche, 1954a). (Transcription conventions are provided in the appendix.)

The intonation is rising toward the end of Mario's locution (turn 74), which makes it possible to hear the locution also as a question. That is, the locution simultaneously is a constative - its grammatical structure makes a statement - and a question - its intonation moves in the way normally associated with questions. It may be heard as a question to Jeannie as much as to himself about the appropriateness of the constative as answer in the question-answer pair that Jeannie has begun. Intonation does not just mark the locution in specific ways, which written language transcribes in the form of punctuation (comma, semicolon, colon, period, question mark, or quotation mark). In living speech, intonation is an integral part and has important functions, as grammatical marker, as expression of social evaluation, and as expression of affect. Indeed, there are strong correlations between prosodic features and psychological states (Scherer, 1989). Intonation and other prosodic features that correlate with emotional states are not produced consciously and often despite the speakers' intentions (e.g., people blush when they talk about something embarrassing or tell a lie). Thus, an affective evaluative tone colors the experience in this situation in addition to any cognitive experience that one might detect; the evaluative tone provides testimony rather than cognitive comprehension of what is happening. Such testimony is typical of the witness rather than of the detached and uninvolved theoretical spectator. As witnesses, the participants in this episode are affected in and by a situation even prior to comprehending cognitively the kind of event that we are involved in and what is happening to them.

\section{Saying is responding, evaluating, exposure}

As in the preceding situation, the locutions that Mario and Thérèse produce constitute summons to Jeannie, not in the least because Mario appears to offer a question (rising intonation) in addition to a statement ("because we are supposed to write it" [turn 74]). That is, if we take Mario's locution as the point of reference, then 
it constitutes a second turn with respect to Jeannie's earlier locution and a first turn to her subsequent locution. Each locution, therefore, has a double orientation, both backward, as social evaluation, and forward, as a candidate for another sequentially ordered turn pair of some kind. There is therefore a reciprocity, a double rather than a single one-for-the other, expressed in the locutions that Jeannie and Mario have produced. This reciprocity leads to the unitary nature of a conversation, which contrasts the constructivist perspective of a conversation as an additive phenomenon where individual subjects give and take.

Emphasizing the interrogative "where," Jeannie proffers another candidate for a question about one of the two composites $(3,6)$ that add up to nine dollars in the piggybank and repeats the "three" from the preceding question (turn 76). In the repetition, she also emphasizes that the question is about the "three," co-articulates that the preceding answer candidates are not sufficient or insufficiently explained, and, in this, provides an evaluation of the preceding locutions. Thérèse says "donno?" with rising intonation (turn 73); and Mario articulates, following several interjections, a candidate answer: "the wedding thing there" (turn 78). (He actually mixes the two languages by saying "the wedding chose [thing] there.") Again, the intonation rises towards the end of the locution, which allows us to hear it as a question rather than a constative. At the same time, he also raises his gaze as if looking for Jeannie's reaction to (evaluation of) this answer (Fig. 1a).

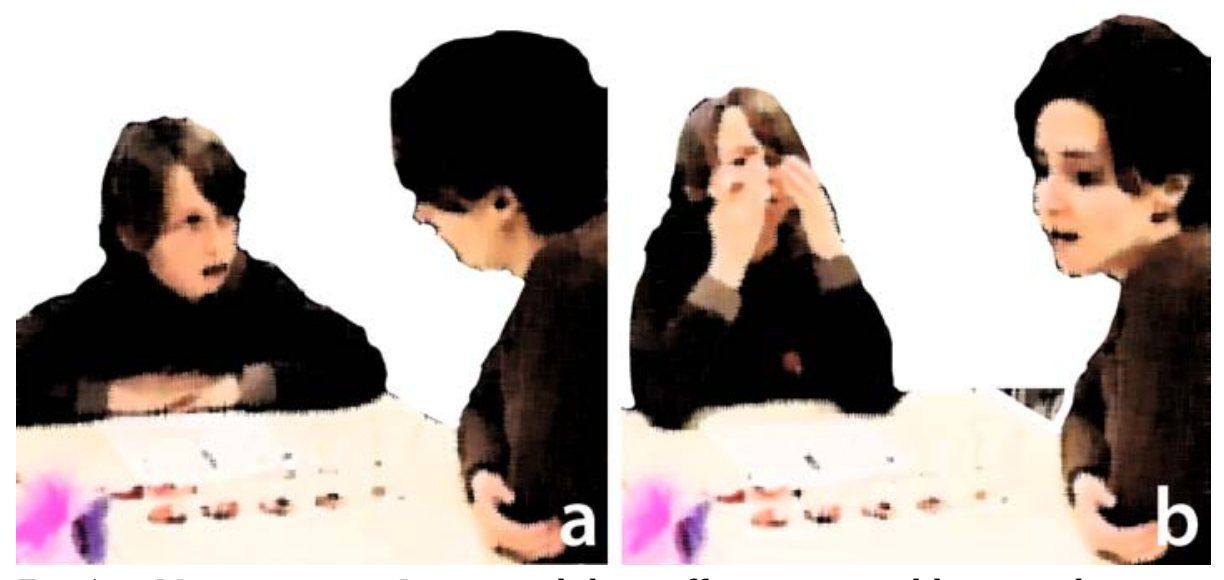

Fig. 1. a. Mario gazes at Jeannie while proffering a possible second turn to complete the offered question-answer turn pair. b. Jeannie sighs, as in exasperation, turning her face away from Mario, who grimaces, as in desperation, and covers his face in his hands.

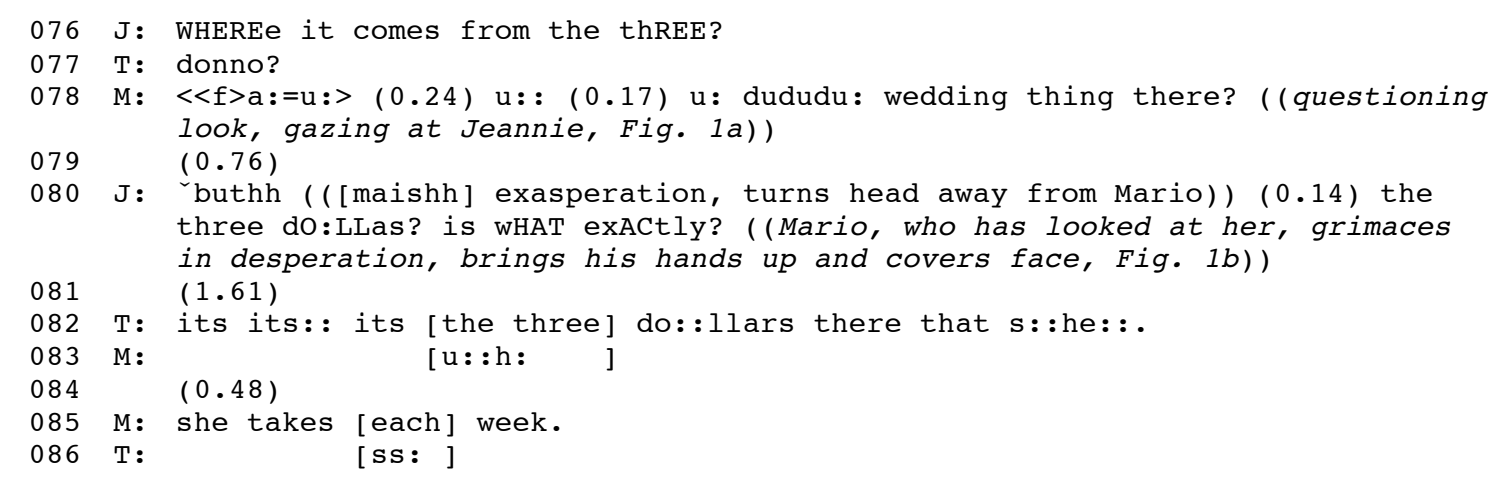




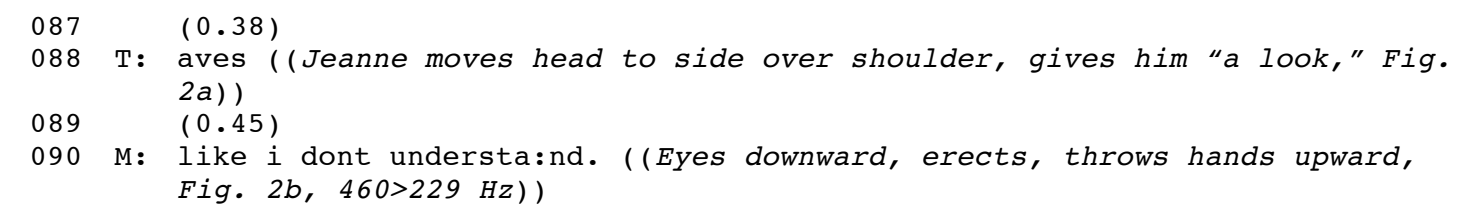

This second turn in the pair not only is social evaluation and a marking of the effect (perlocution), but also, again, exposure to the other. In producing the locution "dududu wedding thing there?" (turn 78), Mario not only proffers a possible completion of a question-answer turn sequence, a confirmation (evaluation) of the first turn as a legitimate question, but also exposes himself to a subsequent evaluation of what he has said (available on after his Saying is completed). This evaluation comes in the form of a literally exasperated "buthh" (turn 080, "hh" means exasperation of breath). There appears to be an incomprehension on her part about why Mario does not understand, which would be an incomprehension preceding the express comprehension of events (Romano, 1998).

Many educational researchers have been critical about the forms classroom discourse often take, where the teacher initiates, a student responds, and the teacher evaluates, an ordered and orderly turn-taking sequence that is often better known under the acronym IRE. Such a sequentially ordered turn sequence never can be ascribed to one person, as it always takes the contributions of several speakers who, in this way, co-produce it. Here, however, more is at stake. Mario not only contributes to the production of the sequentially organized IRE routine but also appears to seek rather than avoid the social evaluation on the part of the teacher the intonation rise as in a question that might be glossed as saying, in a constative form, "The wedding thing there" followed by a query, "Is this right?" or "Am I right so far?" Both speakers are oriented towards and contribute to the reproduction of this often-vilified feature of classroom talk. Jeannie's initiation is in fact already a response, to the historical situation in which Jeannie (as Mario), institutionally located differentially, responds (Chrétien, 2007); and every utterance already is a social evaluation (Bakhtine [Volochinov], 1977). Viewed in a historical context necessary to understand events (Nietzsche, 1954a), the IRE routine takes on a more positive ethical coloring. A post-constructivist ethics, which abandons the causeeffect reasoning underlying the IRE concept, leads us to a different appreciation of certain classroom discourse features. 


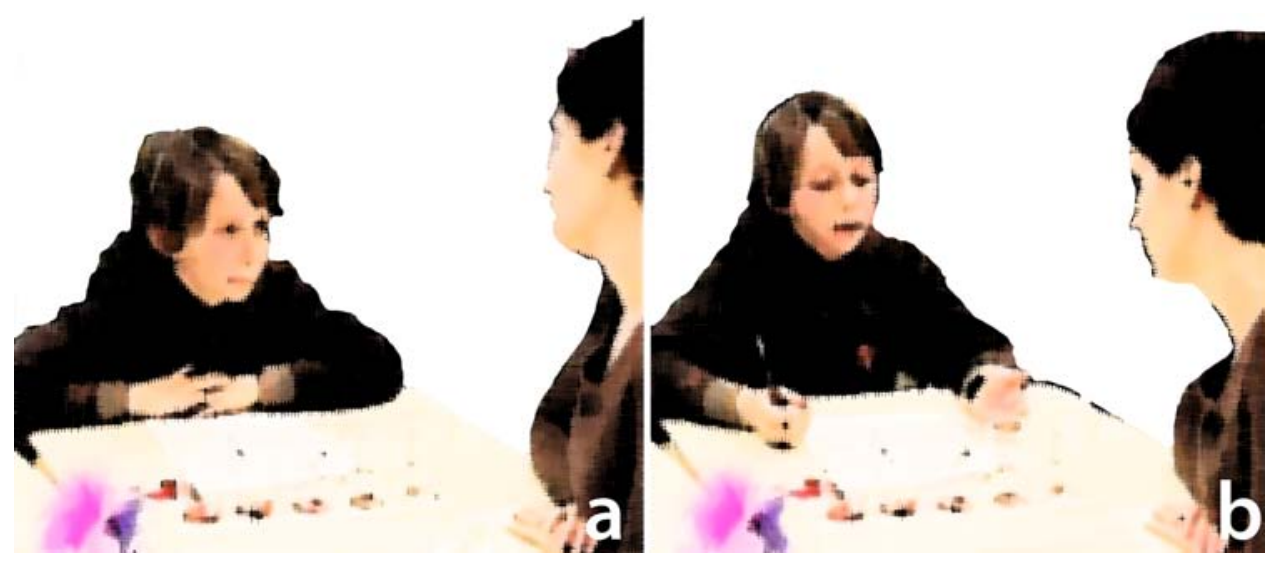

Fig. 2. a. Mario has proffered a candidate answer and Jeannie "gives him a look." b. Mario throws his hands palms upward while saying, "I don't understand."

\section{Saying is affecting}

There is a considerable pause - the length of which is approximately the longest pause that teachers tend to allow for students to answer - before Jeannie produces a "but" followed by clearly hearable outward breath ("hh") with an intonation that is close to a sigh. She turns her head away and toward the camera, as if trying to see whether her (affective) expression has been noted. (In this situation, the affective expression - i.e., exasperation - likely was produced without being intended, and it is after the fact that Jeannie checks on the camera.) She utters, with a rising intonation, "the three dollars?" and then continues, again with rising intonation, "is what exactly?" (turn 080). As any other speaker would do, even though most are not aware of this, she rephrases the questions or rearticulates a statement in the same or different ways when the addressee provides evidence of not having (physically) heard or (conceptually) understood. Mario's face begins to grimace as if in desperation; he pulls up his hands and covers his face with them (Fig. 1b). In this grimace is expressed affect, which has come out of the being-affected; it directly follows Jeannie's expression of affect, which I gloss here by the term "exasperation." That is, there is a mutual affection, as exasperation is followed by desperation.

There follows a very long pause, about twice the average length teachers allow for student answers to come forth and then Thérèse ("it's the three dollars there that she..." [turn 82]) and Mario ("she takes each week" [turn 85]), produce in a turn sequence, a constative that can be heard as a candidate for the answer slot. There is a pause. Thérèse then produces an interjection and at that time, Jeannie turns her head as if gazing over her shoulder right at Mario, as if she were saying, "What are you talking about?" (Fig. 2a). Mario drops his gaze, as if in shame, then brings his upper body up and backward, and in doing so, also moves his hands forward, opens the palms and turns them upward and thereby exposing them (Fig. $2 \mathrm{~b}$ ) while producing the locution "like I don't understand" produced with the intonation characteristic of a constative (turn 090).

\section{From a metaphysical conception of ethics and its critique ...}




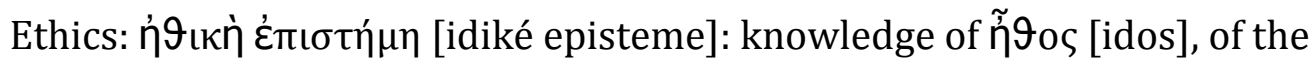
inner attitude of humans and the manner in which it determines their behavior. (Heidegger, 1961, p. 92)

If we looked at the fragment through one of the common theoretical lenses, which attribute actions to individuals and their agency, we might gloss what is happening in a way that attributes deeds to Jeannie and Mario: As part of the attempt to allow Mario to make the sought-for abstraction - amount = number of weeks $* \$ 3+\$ 6$ - Jeannie asks him about the nature of the $\$ 3$ in the piggybank after week 1, which the children have represented using 3 red chips, but which is marked in the table of values by a yellow highlighted slot. When none of the three children (Aurélie does not even contribute to the conversation here but has given signs of abandoning the task) offer an appropriate answer, Jeannie asks again. Mario then tentatively offers an answer in which he talks about a wedding, though there was nothing in the situation related to a wedding. There is an expression of exasperation, an expression that may be indicative of Jeannie's witnessing consciousness of the problematic situation and of her evaluative expression. Just as she produces the "buthh" (Fr. maish ) - exasperation, literally achieved in the forced aspiration transcribed as "hh" - she turns to look at the camera (operator), who is thereby acknowledged as the witness. She then turns back, reorients towards Mario, and repeats the question about the three (dollars). In this perspective, each speech act is understood as the consequence of the speaker's intentions. Because intentions exist prior to the act, these can be compared to some ethical norm. Characteristic of this orientation are those instances in life where someone is told that "S/he should have thought before acting," "S/he should have known that this is a hurtful comment," and so forth. The origin of this way of thinking about the relation between ethics and practical action comes from the ancient Greek, who separated abstract and immaterial ideas (theoria) from practical actions in a material world (praxis).

In the opening quotation to this section, the author articulates ethics as a form of knowledge (theoria) of/about something, here the inner attitude that determines and thereby is external to actual, practical behavior (praxis). It is fundamentally a metaphysical position, whereby some knowledge/idea (theoria) is said to be responsible for something in the material world (praxis). In the metaphysical tradition, ethics is something in the mind of the individual, who, in fact, merely constructs a specific instance of ethical ideas that transcend the human being. The pinnacle of the metaphysical tradition is achieved in Kant's articulation of abstract and practical ethics - he explicitly entitles his project as the "metaphysics of morals" (Kant, 1956a, p. 326). The Kantian approach is constructivist, placing the individual subject at the center of the self-constructed knowledge: "A person is that subject, whose actions are susceptible to an imputation" (p. 329), where imputation is "the judgment whereby someone is seen as the author (causa libera) of an action, which then is called an act/deed (factum)" (p. 334). Acting ethically means to act in a manner without being forced (e.g., by law) so that the underlying rule could serve as 
a common maxim. Kant formulates ethics as a "doctrine of virtues," that is, a "doctrine of the duties that are not governed by external laws" (p. 508). In Jeannie's case, for example, this would mean that she would not deliberately hurt her students - e.g., by ridiculing them, calling them names, or putting them in stressful situations. However, this Kantian position is naïve and problematic, because it supposes that the individual could know in an unproblematic manner what is good for humanity as a whole (Nietzsche, 1954b). This author also writes about the fact that once we have an understanding of the practical world as it is, then the Kantian pursuit of "things in themselves" will be a harmless and irrelevant endeavor (Nietzsche, 1954a). From the post-constructivist perspective taken here, the Kantian approach constitutes "gnoseological and ethical solipsism" (Bakhtin, 1984, p. 177)

Despite the critiques of Kant's ethical position on the part of Nietzsche and other philosophers, the Kantian perspective on knowledge was taken up explicitly in the constructivist formulation of knowing and learning (e.g., von Glasersfeld, 1989) and in recent constructivist formulations of ethics (e.g., von Glasersfeld, 2009). Here, too, the ethical question is something relegated to the mind, as can be seen from the statement that "we use our construction of 'others,' who seem to have action rules similar to our own, as the foundation of a second-order viability" (p. 118). It is evident here, that the constructivist position fails to recognize the irreducible nature of collective responsibility to individual responsibility (Chrétien, 2007), a collective responsibility that "cannot be reduced to the sum of individual actions" (p. 194). Without this tie between the two, there is no way that I could answer for myself and answer before the Other (e.g., court, society). There is a difference, however, between Kantian and modern constructivist ethics in that the former leads to a generalized form of ethics whereas the latter leads to an intra-personal ethics taken to be viable in the world. There is, however, no indication about how human beings could ever share an ethical ground or how the individual would ever come to construct ethics in the first place. The constructivist approach, because it is concerned with a constructed ethics in the mind, has actually no place for the individual in its dialectical relation with others and, therefore, for the grounding of morality in historical society and culture. Although the concept of caring emphasizes relations, it, too, is plagued by the same problem as the constructivist approach, because caring is the effect of an intention: "People who care usually do so naturally and directly because they want to respond positively to those addressing them" (Noddings, 1984/2003, p. xv). The problem is this: The individual, "the one who is actually thinking and who is answerable for his act of thinking," is "not present in the theoretically valid judgment" (Bakhtin, 1993, p. 4), leading to an absence that makes it impossible for constructivist approaches to ground ethics in a relation.

In a constructivist approach to ethics, we would analyze lessons generally and the fragment featured here particularly in terms of actions that spring forth from intentions. The opening locution is said to be a question that is attributed to Jeannie independently of what has gone on before, the cultural and historical nature of the setting, and what follows; Mario's locution similarly is totally attributed to him, independently of what has gone on before, the cultural and historical nature of the setting, and what follows (e.g., Roth, 2008). The categorical imperative exists in 
different forms, but in each case presupposes the act to be founded in an intention that precedes it: "Act only according to that maxim whereby you can at the same time will that it should become a universal law without contradiction." This formulation becomes problematic when considered from the perspective of the conversation analytic approach, where the effect of a locution, whatever the illocution (intention) might have been, is known only in and through the locution (action) of the respondent.

Once the effect is known, a cause can be attributed - i.e., a locution is question, an insult, a statement, a request, and so on. That is, in the conversation analytic approach, the produced act and its intention, on the one hand, and its effect, on the other hand, cannot be separated - especially not into a cause-effect relation because it is only through the effect that a cause can be attributed. Neither Jeannie nor we can evaluate turn 80 ("buthh ... the three dollars is what exactly?") until we know how it has been heard and how it has affected Mario (or his peers). It is through his verbal and affective expression that we come to know that there has been a negative effect (increased frustration). The traditional formulation of a cause-effect relation is also problematic when viewed from the perspective of the event, which explodes the cause-effect dimension of practical action (Nietzsche, 1954b). Once the causeeffect figure of reasoning is put out of play as a myth, the normal Kantian (constructivist) attribution of responsibility implodes. Thus, in the answer to the rhetorical question "Yet is it really the case that transcendent self-activity is ... the self-activity for which I am individually answerable?" (Bakhtin, 1993, p. 6), the author answers: "No one, of course, will claim something like that" (p. 6). We cannot make an ethico-moral judgment based on a single locution, because, as part of the speech act, it takes a second locution (or other expression) to conclude the act so that we can make a determination of causation.

Theoretical cognition alone, as it is considered in the constructivist (Kantian) position, cannot explain why there should be affect involved in ethics in the manner it is observable in the present instance. That is, we see that in and through their relation, Jeannie becomes exasperated and Mario gets frustrated; it is in their own expressions that they make available their evaluations of the affective expressions of the other. If, however, we just looked at the cognitional act, we would lose our phenomenon of interest (Bakhtin, 1993). Thus,

the detached content of the cognitional act comes to be governed by its own immanent laws, according to which it then develops as if it had a will of its own. Inasmuch as we have entered that content, i.e., performed an act of abstraction, we are now controlled by its autonomous laws or, to be exact, we are simply no longer present in it as individually and answerable active human beings. (p. 7)

The perhaps most advanced solution to the dilemma provided by the cognitive/interpretive position may be in the formulation of practical wisdom, which "consists in inventing conduct that will best satisfy the exception required by solicitude, by betraying the rule to the smallest extent possible" (Ricœur, 1990, p. 312). But this solution does not get us out of the problem, for the subject still would 
invent behavior before performing the deed and a rational comparison of the rule in the context of the situation at hand. If Jeannie cannot know beforehand what she has done - asked a question, made an evaluation, hurt someone - then she cannot beforehand minimize the distance between abstract ethics and the concrete performance of a deed the effect of which is known only after the fact.

Because listeners open up to the Saying as it unfolds - Bakhtine [Volochinov], 1977 notes the active nature of reception of other speakers' speech - they are affected before actually knowing the Said - which is where we obtain the connection between thinking, irreducibly intertwined with speaking (Vygotskij, 2002), and affect that alone allows us to understand the "fullness of real life," the "living motives, interests, impulses of the thinker" (p. 54). The constructivist approach makes it impossible to comprehend the influence of affect on cognition and volition. That is, that which transcends the material world - ideas, intentions, conceptions, or ethics - cannot be that for which I am responsible. Responsibility comes into play when I act in the real world, which is transformed through my act (deed) and therefore is affected irreversibly. Thus, in the real world, my very presence (acting, being) means responsibility, a responsibility more radical than any responsibility (ethics) we can think of - because it is responsibility for our unavoidable irresponsibility. Because we are inextricably related to the material world and to others and because practical understanding always precedes, accompanies, and envelops theoretical understanding (Ricœur, 1986), there is responsibility more ancient than human memory:

To maintain that the relation with the neighbor, which uncontestably accomplishes itself in the Saying, is a responsibility for the other, and that Saying is "answering for the other" means no longer finding a limit or a measure of this responsibility that in "human memory" has never been contracted and which finds itself at the merci of freedom and destiny. (Levinas, 1971, p. 41)

It is in the exposure to the other that comes with speech that we can find the ethical relation that undoes the Kantian (constructivist, metaphysical) ethics: "It is in the risky discovery of oneself, in sincerity, in the rupture of interiority and the abandon of all shelter, in exposure to trauma, in vulnerability" (Levinas, 1978/2004, p. 82). In a post-constructivist ethics, we view the Saying not as an expression of something pre-existing but view the Saying, because of its expressive nature, as a resource for the speaking subject to discover itself in the Said (Merleau-Ponty, 1945; Vygotskij, 2002). It is to such an ethics that we now turn.

\section{... to a post-constructivist conception of ethics}

The post-constructivist approach to ethics that I articulate here hinges on the two-sided nature of living speech, whereby (a) any word irreducibly belongs to, and is spread over, speaker and listener simultaneously (i.e., its synchronic dimension) and (b) any speech act unfolds in time and is spread diachronically across two 
consecutive speakers who also listen to each other. There therefore exists a two-fold dehiscence, one deriving from the spread over subjectivities and the other from the spread over time.

\section{Proposition is Exposition is Exposure}

The Saying is proposition - proposition to the neighbor, 'signification loaned/dealt' to the Other. (Levinas, 1971, p. 40)

The saying is exposition of one to the other. Exposition here has a sense very different from thematization. The one exposes itself to the other as a skin exposes itself to that which wounds it, as the cheek offered to the smiter. (p. 44)

We may characterize the traditional conception of the locution as the speakers' making propositions, and, in so doing, their imposition of "meaning" on or contribution of "meaning" to the conversation. In the post-constructivist ethics outlined here, the opposite, if anything, is the case. In the presentation of the fragment, I articulate how speakers and listeners expose themselves to others. Speaking is exposition, possibilities of signification offered up to the other, who imposes signification that shapes the situation - Derrida (1996) denotes this situation as the "monolingualism of the other." The direction of the imposition, therefore, goes the other way, that is, from listener to speaker rather than the reverse, as it does in the constructivist approach. The semantics of the word exposition includes "exposure." Thus, I focus our attention here on the fact that exposition names the process of putting something (out) into public view; but such exposition immediately implies exposure, exposing oneself to the public. It names the process of making a statement, of setting forth or declaring in speech (writing). When Mario utters what is a tentative candidate in a question-answer turn sequence, he puts something into public view - here Jeannie, the teacher, and his two peers.

In attending and listening to Jeannie, Mario also exposes himself. While words furl from Jeannie's lips, all the while her Saying is unfolding, Mario cannot know what Jeannie will have said once the locution has ended and the Said is available in its entirety. That is, he exposes himself to the unknown, to something that is coming at him, but which he will know as the Said only at the end. At this instant in the happening (the unfolding event, the eventing of the event), therefore, there is a double exposure, each interlocutor exposing him-/herself to the other. In the face of the other, each participant is vulnerable, subject to being affected, subject and subjected to what is happening. Such exposure brings responsibility, but on the part of the other. That is, because he has been called upon in Jeannie's address, Mario is responsible prior to his intention to act. Similarly, Jeannie performs not because she somehow feels responsible - which may also be the case; rather, much more originarily, she is always already responsible because she is speaking, calling forth the other, and thereby affecting him/her. But this speaking already is a response in and to a cultural-historical context rather than an originary beginning. Speaking 
implies responsibility one for the other prior to any conceptualizing of what is to be said.

The exposure that comes with Jeannie's or Mario's speaking constitutes "supreme passivity," an "abandon of the sovereign and active subjectivity posited as 'self-consciousness', as the undeclined subject, or as the subject in the nominative form" (Levinas, 1971, p. 41). This leads us to a form of inversion of intentionality, where the autonomous ("undeclined") speaking subject, rather than acting upon the world, first and foremost is subject to and subjected to the other. Being a patient, the one who undergoes something, the subject appears in the accusative form. It constitutes an inversion of the constructivist (Kantian) subject, which is the origin of its cognitive structure, the viability in the world of which is the intentional project of the autonomous subject. Thinking speech from the perspective of the autonomous subject would "amount to a prior representation ... as though speaking consisted in translating thoughts into words and consequently in having been first for-oneself and at home with oneself' (Levinas, 1978/2004, p. 81). The proposed postconstructivist ethics thereby overturns the primacy of the subject and its mind, a view that also changes how we think subject, subjectivity, and identity. ${ }^{4}$

The transcription of the lesson fragment shows that when Jeannie speaks, Mario is listening; when Mario is speaking, Jeannie is listening. As we can see from the emotional dimensions of their replies, they are affected in and through this exposure. Each, therefore, in his/her turn opens up to receive, and this opening up is part of their response (Bakhtine [Volochinov], 1977). Here response is understood as a category that unites listening and replying into one single process, because "listening is an act of speech, and even the first of all" (Chrétien, 2007, p. 31). It would be impossible to reply - etymologically derived from Middle French reploier, to send back - if there had been no listening to the original locution; and this reply is grounded in and inseparable from the listening (Waldenfels, 2006). This orientation toward the speaker on the part of the listener constitutes part of the active reception, which occurs at the level of inner speech (Bakhtine [Volochinov], 1977). Here an "utterance is received, comprehended, and evaluated" (p. 165). There are two dimensions to the active orientation of the listener. First, "the utterance of another is replaced in the context of a factual commentary (which confounds itself partially with what is called the apperceptive ground of the utterance)" (p. 165). At the same time, an answer forms itself. These two parts are irreducible moments of the same phenomenon: the diastatic and dehiscent nature of the response. These two moments "can be isolated only in abstract terms" (p. 166). In this way, "the listener becomes the speaker" (Bakhtine, 1984, p. 274).

The specificity of the kind of ethics Levinas proposes arises from the fact that the one who makes a proposition exposes a text, and in this exposition thereby also exposes him-/herself: Addressing the other is speaking-for-the-other. Jeannie does not just summon Mario, but exposes herself; Mario does not just expose himself in the response, but summons Jeannie simultaneously. Here, those who expose

\footnotetext{
${ }^{4}$ The complexity involved in such a rethinking certainly is one of the reasons why it takes Ricœur (1990) an entire book to articulate the questions of Self, Other, and their ethical nature of their relation.
} 
themselves, who thereby are vulnerable, also are those who speak for and address the other, which is, for whom they bear responsibility in uttering. They are also those who, in responding, socially evaluate the other. The hyperbolic nature of the Levinasian ethics comes from the fact that it is the vulnerable, "the persecuted one [who] is liable to answer for the persecutor" (Levinas, 1978/2004, p. 175). It is here where the absoluteness of passivity and the responsibility lies. Speakers, who expose themselves in their Saying, and, therefore, are the equivalents of the persecuted ones, have to answer for the persecutors, the ones whom they address in and during Saying - because they not only call on the other but also call for the response of the other (which begins with their listening/attending and ends in their own completion of a Said).

Exposure and the associated passivity are fundamental to post-constructivist ethics I propose. Thus, the passivity of the Saying is "an exposure to the other, it is signification, is signification itself, the-one-for-the-other to the point of substitution - but a substitution in separation, that is, responsibility" (Levinas, $1978 / 2004$, p. 92). Here we can hear in the "substitution" a substitution of the traditional subject, conscious of its actions that it deploys while doing so to the dialectical construction of the subject, which is also subject and subjected to the condition. It is not Jeannie who determines the "meaning" of her locution "why is the three in yellow?": It is what Mario hears, as expressed in his reply, that will set up the next speaking turn and, therefore, determine the movement in and of the conversation. Relative to the constructivist approach, it is not Jeannie but Mario who "calls" the nature of the sequentially ordered turn pair. (Pertinent here, the baseball umpire Bill Klem is often quoted to have said, "It [throw] is nothing [ball or strike] until I call it.") There is therefore a substitution of the traditional subject: Jeannie is in the position of the accusative. Maintaining that the relation with the other accomplishes itself in the Saying also means "glimpsing an extreme passivity, a passivity without assumption, in the relation with others and, paradoxically, in the pure saying itself" (Levinas, 1971, p. 41). "Without assumption" here means that the passivity is not taken on actively (Thomas, 2004); it is passivity more radical than any passivity that we can think of or take because it pre-exists and we find ourselves in it. That is, the Saying in general signifies the turning toward and opening up to the other, intimacy, and opening up means opportunities to be affected, vulnerability.

Speaking exposes itself to the listening, and listening is exposed to the speaking. That is, there is not merely a sequentially ordered taking of turns as theorized in speech act theory but both Jeannie and Mario are implied in the turns of the respective other. Each word, therefore, represents a reciprocal relation rather than the one typical for the constructivist (intentional) approach, where the locution is taken as an expression of the self. Levinas (1978/2004) denotes this reciprocal relation by the term of the "one-penetrated-by-the-other" (p. 85), which leads him to unfold a discourse that includes the persecutor and the persecuted, the violence of denuding and being denuded: a traumatic form of violence. The special and sometimes difficult to understand nature of Levinasian ethics derives from this interpenetration of the interlocutors, here Jeannie and Mario.

In the constructivist literature on pedagogy and curriculum, there is an emphasis on the "meanings" that speakers articulate, make, or have. Thus, Mario would have 
said to have (not) made sense of Jeannie's "question," and Jeannie would have been said to construct the "meaning" of Mario's responses - him not understanding and, as a consequence, reiterating the question. In the post-constructivist ethics proposed here, the issue of signification is reversed, or, perhaps better, it is but a moment of the whole "being-as-event" or "world-as-event" (Bakhtin, 1993). For one, the Saying prevents sense to be attributable to the speaker him-/herself. This is so because in the Saying, "the for-the-other, the passivity more passive still than any passivity, the emphasis of sense, is kept from being for-oneself" (Levinas, 1978/2004, p. 85). In this formulation, sense (a word which in many Anglo-Saxon texts might appear as "meaning") is kept from being for-oneself, which renders illegitimate to talk about "Jeannie's sense ['meaning']" or "Mario's sense ['meaning']" in the way we find it in many analyses of classroom interaction. Vygotskij (2002) agrees with this position when he says that the "word is in consciousness that which according to Feuerbach is absolutely impossible for the individual but possible for two" (p. 467). When Jeannie speaks, it is not for her, it is for Mario. She seeks an expression for Mario, rather than for herself, and this is especially salient in her repeated attempts - when summoned - to rearticulate the locution so that it becomes an intelligible first moment of a question-answer pair.

\section{Affect and affectation: exasperation and frustration}

In the exasperation she expresses through her body (posture change, voice), Jeannie provides an evaluation of the situation as a whole, which includes and pertains to both Mario's apparent difficulties in producing a sought-for answer and her own inability to ask in a manner that would allow a satisfactory questionresponse pair to evolve. That is, the first locution (turn 69) is not such that it allows a second locution to come forth so that it produces the premise for a positive evaluation, the third turn of an IRE sequence. Similarly, Mario provides an emotive evaluation of the situation in the fragment, which we might gloss as a form of frustration with the situation as a whole tending toward despair, for there now have been repeated joint attempts at producing what would become the premise of the next pedagogical move to explain the amount of money (number of chips) in the second goblet.

In this fragment, we therefore observe how the interlocutors affect each other in and through their talk and other forms of bodily expression including prosody; and this affectation is reflected in affective expressions. Thought, realized in the Saying, and affect, realized in the various bodily expressions including intonation, no longer are separate but constitute different moments of the same unfolding event irreducible to Jeannie's or Mario's individual or collective agency. Moreover, the interaction participants Jeannie and Mario do not merely deliver some (cognitive) content, as this would be in the constructivist framework, but they provide these expressions for each other and make available how another's expression has affected them. Thus, for example, the intonation that goes with "but" together with the hearable expiration "hh" (turn 080) followed by the third instantiation of what can be heard as a question about the nature of the "three" (dollars, yellow chips) evolves into Mario's grimace and the covering of his face with his hands. This is a 
change from earlier locutions and expressions that have been much more assertive. We therefore have a double effectuation, whereby a first turn pair affects the first moment of the response, and the second turn pair, the second moment of the response, affects the first speaker, which is made visible as the second part of the second turn pair, for which the second locution is the first turn.

The importance of theorizing affect as an integral part of interaction and of bringing affect into the analysis becomes very clear in this brief fragment from a classroom episode. Both participants orient to and engage the other. Speakers are not mere dispassionate cognitive devices but the situation, which we may gloss as a failure to ask the right question and to give the right answer, is associated with affect made available publicly through emotional expressions upon which the participants themselves act. These expressions are reflections of the material situation but at a level that differs from cognitive consciousness (Leontjew, 1982). We most clearly see this in the sequence where Mario, in providing a locution as candidate for the second slot in the question-answer sequence, offers up a candidate answer (turn 78). It is an offer that the rising intonation marks in a way that we may gloss as, "Here is my answer but I am not certain about it" or "Is this the answer you are looking for?" The expression of exasperation and the repetition of the question, which constitute the social evaluation part, the effect (perlocution), mark the answer as inappropriate.

Jeannie is not just asking for the nature of the three dollars ("the three dollars is what exactly?") but, in its repetition, in asking the same question again, the locution also marks that the preceding answer is not the expected one. The term "but" functions as adversative conjunction and as interjection that expresses opposition, objection, or protest (Oxford English Dictionary [OED], 2011). There therefore is a double evaluation, the totality of which is negative - not because we, the observer participants "interpret" the instant in this way but because the participant concerned, Mario, produces a concomitant expression as the second member of a turn pair characterized by a negative evaluation across both cognitive and emotive dimensions: He has been affected in attending to Jeannie's expressions and his evaluation expresses itself in his grimacing, as in desperation, and his covering of his face.

From the aforesaid we learn that Saying is contact and, therefore, already wounds or caresses (Levinas, 1971). Because of the two-sidedness of tact, within and outside the body, it also is associated with denuding, penetration, wounding more than the outside, and going to the very heart of being. With contact, there also is tact, contingency, and contamination, all with etymological roots in the Latin verb tangere, to touch. When we listen to someone else, we may be touched by the said and we are affectively contaminated, i.e., touched without being aware of it, by the intonational forms of the Saying - which sometimes moves us to tears even though we may not want to cry.

\section{Answerability}

Because interaction participants affect each other - and, emotionally speaking, infect each other, because affect spreads like contagion (Vygotskij, 2002) and fuels 
the affect of others (Chrétien, 2007) - there is a form of responsibility that is prior to any intention. This responsibility, or answerability, comes from the very praxis of speaking, which is why both Levinas and Bakhtin include it as lynch pin in their ethics. The latter uses the term answerability to characterize the ethical dimensions for each act/deed that we produce: We solicit answers but also are answerable for the solicitation. He does not make an explicit link to the answer in a speaking situation. Levinas does make such a link when he makes the Saying to be the paradigm of ethics (Levinas, 1971). In Levinas's French language, the verb répondre (to respond), in the same way as the English verb to answer, has a different dictionary sense in different constructions. Répondre à is equivalent to "to answer (someone)" or "to answer to (a charge)"; répondre de translates as "to answer for [charges in regards to]." That is, in providing responses, speakers not only answer to but also answer for something. These two aspects are irreducible and therefore cannot be separated, as stated in the third introductory quotation to this text (Chrétien, 2007). Whereas Bakhtin attributes this responsibility to the person producing the locution, Levinas actually theorizes the beginning in the reception, thereby making the listener answerable for the Saying of the speaker.

In Bakhtin, every act is answerable, not just the act of speaking. This is so not in the least because the answerable act or deed is "the actualization of a decision inescapably, irremediably, and irrevocably" (Bakhtin, 1993, p. 28). The answerable act/deed "is this affirmation of my non-alibi in Being that constitutes the basis of my life" (p. 42). We can hear this answerability in two ways. First, the author of the act or deed is answerable, that is, responsible for the act, which, in an ever-changing "world-as-event," is once-occurrent and therefore cannot be taken back. This world is not abstract, but, qua practical and inhabited world that conditions us and that we condition, is at our "mutual disposition" (p. 54). Thus, my act changes the world, making it a different world at the disposition of the other. But answerability also means that the author of the act/deed is answerable for making an answer possible, that is, in being intelligible on the part of the other. That is, the utterance is for-theother, and to have this characteristic, the address needs to be such that the other actually can understand and answer. This allows us to suggest that there is "an architectonic interrelationship of two valuatively affirmed others" (p. 74). The basic moments of the architectonic are "I-for-myself," "the-other-for-me," and the "I-forthe-other" (p. 54). The synchronic structural and diachronic temporal dimensions of the practical world are captured in the notion of "world-as-event," inherently diachronic, and in terms of an architectonic (i.e., inherently synchronic structure). Values are inherent in the way that this architectonic is structured: The "valuative architectonic ... is something-given as well as something-to-be accomplished, for it is an architectonic of an event" (Bakhtin, 1993, p. 75). Events, in their eventness, are diachronic. In fact, the whole world is unitary in content because it is to be conceived in the category of "world-as-event" (p. 32). Bakhtin notes that the contraposition of $I$ and the other has not been stated explicitly (at the time he composed his essay); but it has indeed occurred in the work of Levinas generally.

Bakhtin develops his ethics in the context of art and the relationship between the author of a piece of work and those who render social evaluation. This allows us to extend the post-constructivist ethics articulated here from speaking to writing 
and any other form of human expression. The mutual responsibility and guilt of the author (of an utterance) and respondent is expressed in terms of the relation between artist (poet) and the consumer of art (reader):

The poet must remember that it is the poetry which bears the guilt for the vulgar prose of life, whereas the man of everyday life ought to know that the fruitlessness of art is due to his willingness to be unexacting and to the unseriousness of the concerns in his life. (Bakhtin, 1990, p. 2)

The "architectonics of answerability" refers to the fact that the reader is giving life to the art (text) produced by the artist. Translated back to the communicative relation with which this article begins, it is the listener who gives life to the text produced by the artist; it is the relation between the author and recipient that affirms the diachrony (dehiscence) of the word.

\section{The Saying (le Dire) as dialogical/dialectical paradigm of post-constructivist ethics}

Responsibility always remains a response to that which precedes us and to that which surrounds us. (Chrétien, 2007, p. 195)

There is an integral relation between evaluation and signification because "every actualized word not only contains a theme and a signification in the objective sense ... but also an evaluative accent" (Bakhtine [Volochinov], 1977, p. 147). Every word that Jeannie utters in the conversation, as every word that Mario produces, contains this evaluative accent. Even Jeannie's first question in this fragment is in response to something that precedes the instance, Mario's raised hand that summoned her to the group of desks in the narrow sense and a response to the institution and her institutional role in a larger sense. Jeannie asks the question because she is a teacher, whose role is to assist children in learning mathematics. As a consequence, without evaluative accent, the word as such does not exist. "The most obvious level, which at the same time is the most superficial of the social evaluation contained in the word is transmitted by means of the expressive intonation" (p. 147). "Being-for-the-other, in the manner of the Saying, is therefore exposing to the other that signification itself" (Levinas, 1971, p. 42). This is to say that this reversal of the ethical question involves the exposition rather than imposition of signification ("meaning").

Each Saying is an irreducible moment of conversation, which can be viewed as the exchange of signs (words) that are or are made common to the interlocutors. Precisely because Mario signals a problem with understanding Jeannie's opening locution, the communication is shaped to deal with this "incomprehension" so that the exchange eventually is enabled. Both parties are responsible for themselves and for the other because "collective responsibility and co-responsibility form a constitutive dimension of social existence" (Chrétien, 2007, p. 196). In the economic exchange process, the things exchanged have equal value, which in fact is different 
value - use-value and exchange-value (Marx/Engels, 1962). Marx's insights can be transferred to ethics, for in his theory, the value of things only stands proxy for the value of people. In positing the equivalence of values of the things they exchange, human beings posit the equivalence of their mutual labor, and, therefore, the mutual equivalence of themselves as human beings. Thus, "value is a relation between people ... a relation hidden under material cover" (p. 88). In fact, an analysis that replaces the term "commodity" in Marx's Capital with the linguistic term "sign" and examples of commodities with examples of signs produces texts that exhibit structural and semantic family resemblances with post-constructivist philosophies of language and ethics (Roth, 2006). Bakhtin's (1993) theory of ethics, consistent with his (sociological) theory of language, takes on this dialectical (dialogical) perspective of the Marxian exchange, which, by being about the value of human beings, inherently takes on deontological dimensions.

Saying is an event, and events are diachronic and dehiscent - spread out across time and space - which, from a dialectical perspective, requires categories other than nouns to capture these phenomena. The verb is much more appropriate to capture the eventness of the event (e.g., Romano, 1998). It is in the very diachrony of the Saying - a direct consequence that it is a real, practical and temporal act - that the possibility for being affected enters the picture. Understanding the response as beginning with listening - according to the analyses that both Bakhtine [Volochinov] (1977) and Levinas (1971) provide - also is a way of conceptualizing postconstructivist ethics in a diachronic and dehiscent way. That is, as soon as we take the practical action - a real, once-occurrent, and irreversible process - as the point of reference, we introduce the same deontological dimension that we get when we attempt to understand being and the world as (historical) events (Bakhtin, 1993). However, when we consider the Said, which, in its denominative form, presents the world in synchronic manner, we end up with a-temporal and abstracted structure and metaphysical ethics.

Across his work, Bakhtin (1993) builds a non-reductionist, dialectical (he prefers the adjective dialogical even though his work is deeply influenced by Marxian thought [e.g., Holquist, 1990]) theory of the world-as-event. Understanding the world as event requires categories that capture the eventness of the event. For Bakhtin, as for Vygotsky, the spoken/written word (utterance) is such a category. Post-constructivist ethics therefore arises from the fact that "every word has two faces. It is determined as much by the fact that it proceeds from someone as by the fact that it is directed towards someone. It precisely constitutes the product of the interaction of speaker and listener" (Bakhtine [Volochinov], 1977, p. 123). Any word that Jeannie utters in this conversation is for Mario; and any word Mario utters in this conversation is for Jeannie. As a result, the word is the bridge between and common to participants - not just taken-as-shared as constructivist hold it. We may also say that the word is the same and different simultaneously; it symbolizes the inner difference of the same. This inner difference manifests itself in very different ways - diachrony (speaking, responding) and dehiscence (differences in speech intention and speech effect [social evaluation]). It is, as some commentators point out, an explicit attempt to build on Karl Marx's philosophical writings to establish an understanding of humans in their flesh and blood who, in real praxis, not only are 
subject to the reigning conditions but also simultaneously transform these conditions. It is an explicit attempt to understand the human life form as a moving, continuously self-transforming phenomenon.

Kant (1956b) pins moral value to action, which he derives from its formal properties, and associates it with the moral value of the person. As part of a discursive act, the word therefore is associated with moral value of the person (Kant, 1956a). From this perspective, the value of Jeannie or Mario as persons would derive from the particular acts ascribed and imputed to them qua agential subjects. But in the post-constructivist ethics articulated here, the word is attributed to both interlocutors simultaneously. This leads to the fact that the non-coincidence of the word-sign with itself begins in the Saying (utterance [Bakhtin]). The different ways of understanding the word that exist between two speakers is not a result of two subjectivities, each understanding in its own way, but is a result of the originary non-self-identity of the word-sign with itself, which gives rise to different understandings. This is a straight analogy to the situation of Marx's category of value, which manifests itself as use-value or exchange-value of the same commodity to buyer and seller, respectively. In fact, we may pin value directly to the word (signification), which, in analogy to economic value, is use- and exchange-value simultaneously. The co-translator and author of the introduction to Art and Answerability points out the close relations between Bakhtin and Marx (Holquist, 1990). Again, the differences are not the results of different individuals - as constructivist, metaphysical ethics would consider the issue - but a difference of the thing in itself. 5 The dehiscence of the word, itself a diachronic moment spread in and producing time, also is a reflection of diachrony of all processes (Levinas, 1971). It is a diachrony made salient in the notion of the one-for-the-other characteristic not only of philosophical thought but also apparent in the theories of social psychologists (e.g., Vygotskij, 2002) for whom any consciousness of and for self always already is consciousness for the other. This double relation of consciousness, being for the other and being for the self, is reflected in the word "like the sun in a water droplet" (p. 467).

To conclude, the post-constructivist ethics articulated here is grounded in the Saying of speech. The Saying implies opening up, a transcendence of the Self in the direction of the Other. The speaking subject "approaches the other by ex-pressing itself," "in the literal sense of the term by expelling itself out of any locus, neither inhabiting nor stomping any ground" (Levinas, 1978/2004, p. 83). The passivity and ethics in speech therefore does not arise from the fact that we use language that is not our own - we always appropriate it from the other - and, therefore, that anything we can express is but a realization of possibilities that already exist in culture or "ex-appropriation" (Derrida, 1996, p. 50). The radical passivity and the special ethical nature of the relation between Jeannie and her students come with Saying, which, in its performative dimensions, is a form of agency and passivity. This allows us to understand ethics and responsibility as inherent moments of once-

5 This idea is difficult to understand when we imprison ourselves - a choice, and therefore responsibility - in the perspective of/from the individual subject and when objects are considered irrespective of the unfolding events in which they are constitutive parts. 
occurrent life as event rather than as a mentally constructed feature in some immaterial, metaphysical world that has to find its ground.

\section{For a post-constructivist-ethics-to-come in (to) education}

Let us define "ethical intention" as aiming at the "good life" with and for others, in just institutions. (Ricœur, 1990, p. 211, my translation, original emphasis)

It is not unusual for reviewers of academic papers in education to ask: So what? On the surface, post-constructivist ethics may seem to be an abstract idea when in fact there are already endeavors where it is integral to the everyday praxis of schooling. In this paper, I develop a post-constructivist ethics that is premised on the inherent answerability that comes with participating in collective society and life. This responsibility is not something we have to take, but we always already answer to and for something or someone. In our mundane life as teachers, however, we do not tend to be aware of the fact that everything we do has an effect on the world, and, because we share this world with others, we are answerable even for our most insignificant acts (Bakhtin, 1993). As schooling is compulsory, superintendents, principals, and teachers are in institutional and legal positions where their actions have lasting effects on students, who generally are not involved in decision-making concerning what and how they learn. Even the simplest of acts giving a grade, "helping" a student to change topic so that she may not fail physics (even though she does not want), "treating everyone the same," or asking students to pay attention when they in fact linger thinking about what they had just heard may hinder as well as enhance learning. The crux of the matter lies in the fact that in this view only superintendents, principals, and teachers are included in ethical considerations, when the dialogical approach inherent in the post-constructivist ethics includes students as answerable subjects. Working towards the praxis of post-constructivist ethics as outlined here means opening up the possibility for truly dialogical institutions, where stakeholders "am at the 'good life' with and for others." Schools and educational systems that reproduce social inequalities (e.g., Bourdieu \& Passeron, 1979; Willis, 1977) cannot be "just institutions," and, therefore, fail to work towards a post-constructivist ethics.

In and with this text, I articulate the inherent symmetry that arises from speaking, from participating in conversation. An important aspect of the postconstructivist ethics is a dialogical dimension of life that currently is not developed to its fullest in much of schooling. The "basic moments" of "actual life and culture" have the same characteristics as every act of speaking: "I-for-myself, the other-forme, and I-for-the-other" (Bakhtin, 1993, p. 54). Schools, however, frequently do not even have the characteristic of the Socratic dialogue, which is dialogic in form but monologic in content, working towards a singular, pre-given truth (Bakhtin, 1984). Only true dialogue, open in form and content, continually developing as contradictory and incompatible ideas and interests engage with each other, has the potential to overcome the gnoseological and ethical solipsism of the constructivist 
position. Thus, schools and classrooms characterized by a post-constructivist ethics aim at the good life with and for others, that is, aim at developing institutions where all stakeholders participate in cogenerative dialogues that develop common and therefore general interests rather than special interests (Stith \& Roth, 2010; Tobin \& Roth, 2006).

In cogenerative dialogues, teachers and their students frame and solve problems together; they may ask others to join, such as heads of department or principals, when problems seem to become intractable - leading to distributed and collective forms of leadership (Ritchie, Tobin, Roth, \& Carambo, 2007). In cogenerative dialogues, individual participants have no control over the outcomes of the dialogue, and even the form of the conversation may be up for debate. This means that superintendents, principals, and teachers who subscribe to post-constructivist ethics truly adhere to democratic principles and dialogism and give up their will to control school systems, schools, and classrooms, respectively. They work toward a "cosmopolitan 'we' in cogenerative dialogue" to achieve distributed classroom and school management even under the most difficult of conditions such as detention schools in inner-city New York (Emdin \& Lehner, 2006). Consistent with the postconstructivist ethics articulated here, in cogenerative dialogue all participants experience themselves to be subject to and subjected to the collective endeavor as much as being agential subjects thereof. They aim at the good life by working towards the realization of common and therefore general and generalizable interests.

"Just institutions," which embody the ethical intention to work with and for others may arise only when form and content of institutional conversations are dialogic, that is, open to continual change and development. In fact, schools and classrooms, as "just institutions," are never achievable in a strong sense, for if they came to factually exist, they would no longer change and therefore would be dead. This means that whatever stakeholder position we take in the educational process, we have to continually work towards a socially just institution. However, just institutions of schooling, in the same way as democracy (Derrida, 1997), are forever to come (à venir), forever in the future (à-venir). This is the converse side of saying that " $[\mathrm{w}]$ hen dialogue ends, everything ends. Thus, dialogue, by its very essence, cannot and must not come to an end" (Bakhtin, 1984, p. 252). The author therefore speaks of the "ethical unfinalizability of man before his death" (p. 56).

A post-constructivist ethics in schooling, dialogical in form and content, cannot ever be achieved, is not, and never is: a post-constructivist ethics always is ${ }^{6}$ becoming, a "(future) post-constructivist ethics to come." My own praxis during the last year of teaching in a traditional (British-style) private school was working toward such a post-constructivist ethics, forever to come, aiming "at the 'good life' with and for others." Together, students and I worked out - on individual and group basis - how to and what to study to simultaneously meet the provincial curriculum specifications and their goals and interests. We evolved together guidelines for evaluation whereby term grades were a composite of teacher evaluation (35\%),

\footnotetext{
${ }^{6}$ In this case, the "is" has the function of an auxiliary verb rather than that of an existential, which it has in the preceding parts of the sentence.
} 
peer (class) evaluation (60\%), and self-evaluation (5\%), which took into account student-articulated fears that self-evaluations may be too positive and peer (class) evaluations of a semester's work involved more than a single person (e.g., teacher) and therefore should have greater impact on the overall mark of a student. Students were aware that their contributions to the grades of other students would be affecting them; and, moreover, their evaluations of others and self-evaluations would contribute to establishing the trust in a "just institution" of grading. A postconstructivist ethics also means working towards a curriculum that emphasizes students' contribution to collective life. For example, in such a curriculum that "aims at the 'good life' with and for others," students may decide to participate in environmental activisms and contribute to the common good by cleaning up a creek or contributing to the public knowledge about it as an integral endeavor of their ethico-moral commitment (Roth, 2007).

\section{Acknowledgments}

The data used in this study have been collected during a project funded by the Social Sciences and Humanities Research Council of Canada (to Luis Radford). The transcript of the classroom episode also has been published in its entirety in Roth and Radford (2011). I am grateful to Jean-François Maheux, who provided critical feedback to an earlier draft. All opinions expressed are my own.

\section{References}

Bakhtin, M. (1984). Problems in Dostoevsky's poetics (C. Emerson, Trans.). Minneapolis, MN: University of Minnesota Press.

Bakhtin, M.M. (1990). Art and answerability (M. Holquist \& V. Liapunov, trans.). Austin, TX: University of Texas Press.

Bakhtin, M. (1993). Toward a philosophy of the act (V. Liapunov, trans., V. Liapunov \& M. Holquist, Eds.). Austin, TX: University of Texas Press.

Bakhtine, M. (1984). Esthétique de la création verbale [Esthetics of verbal creation] (A. Aucouturier, trans.). Paris, France: Éditions Gallimard.

Bakhtine, M. [Volochinov, V. N.] (1977). Le marxisme et la philosophie du langage: essai d'application de la méthode sociologique en linguistique [Marxism and the philosophy of language: Essay on the application of the sociological method in linguistics] (M. Yaguello, trans.). Paris: Les Éditions de Minuit.

Bourdieu, P., \& Passeron, J.-C. (1979). Reproduction in education, society and culture (Transl. by Richard Nice). Thousand Oaks, CA: Sage.

Brown, T., \& McNamara, O. (2011). Becoming a mathematics teacher: Identity and identifications. Dordrecht, The Netherlands: Springer.

Chrétien, J.-L. (2007). Répondre: Figures de la réponse et de la responsabilité [To respond: Figures of response and responsibility]. Paris, France: Presses Universitaires de France. 
Czarnocha, B. (2008). Ethics of teacher-research. In B. Czarnocha (Ed.), Handbook of mathematics teaching research: Teaching experiment - a tool for teacherresearchers (pp. 79-86). Rzeszów, Poland: University of Rzeszów.

Derrida, J. (1988). Limited inc. Evanston, IL: Northwestern University Press.

Derrida, J. (1996). Le monolinguisme de l'autre ou la prothèse d'origine [Monolingualism of the Other; or, The prosthesis of origin]. Paris, France: Galilée.

Derrida, J. (1997). Cosmopolites de tous les pays, encore un effort! [Cosmopolitans of all countries, another effort!] Paris, France: Galilée. (An English translation is included in On cosmopolitism and forgiveness, London, UK, Routledge, 2001.)

Emdin, C., \& Lehner, E. (2006). Situating cogenerative dialogue in a cosmopolitan ethic. Forum Qualitative Sozialforschung / Forum: Qualitative Social Research, 7 (2), Art. 39. Accessed March 7, 2012 at http://nbnresolving.de/urn:nbn:de:0114-fqs0602390

Heidegger, M. (1961). Nietzsche Erster Band [Nietzsche vol. 1]. Pfullingen, Germany: Neske.

Holquist, M. (1990). Introduction: The architectonics of answerability. In M. M. Bakhtin, Art and answerability (M. Holquist \& V. Liapunov, trans.) (pp. ix-xlix). Austin, TX: University of Texas Press.

Kant, I. (1956a). Werke Band IV [Works vol. 4]. Wiesbaden, Germany: Insel Verlag. Kant, I. (1956b). Werke Band $V$ [Works vol. 5]. Wiesbaden, Germany: Insel Verlag. Levinas, E. (1971). Le dit et le dire. Le Nouveau Commerce, 18/19, 21-48.

Levinas, E. (1978). Autrement qu'être ou au-delà de l'essence [Otherwise than being or beyond essence]. The Hague, the Netherlands: Marinus Nijhoff. (Published by Le Livre de Poche, Paris, France, 2004)

Leontjew, A.N. (1982). Tätigkeit, Bewusstsein, Persönlichkeit [Activity, consciousness, personality]. Cologne, Germany: Pahl-Rugenstein.

Lundin, S. (2011). Hating school, loving mathematics: On the ideological function of critique and reform in mathematics education. Educational Studies in Mathematics. doi: 10.1007/s10649-011-9366-6

Marx, K./Engels, F. (1962). Werke Band 23: Das Kapital [Works vol. 23: Capital]. Berlin, Germany: Dietz.

Merleau-Ponty, M. (1945). Phénoménologie de la perception [Phenomenology of perception]. Paris, France: Gallimard.

Nietzsche, F. (1954a). Werke Band 1 [Works vol. 1]. Munich, Germany: Hanser. Nietzsche, F. (1954b). Werke Band 3 [Works vol. 3]. Munich, Germany: Hanser. Noddings, N. (2003). Caring: A feminine approach to ethics and moral education. Berkeley, CA: University of California Press. (First published in 1984)

Oxford English Dictionary (OED) (2011). Online version. Accessed January 18, 2012 at www.oed.com .

Radford, L., \& Roth, W.-M. (2011). Intercorporeality and ethical commitment: An activity perspective on classroom interaction. Educational Studies in Mathematics, 77, 227-245.

Ricœur, P. (1986). Du texte à l'action: Essais d'herméneutique II [From text to action: Essays in hermeneutics II]. Paris, France: Éditions du Seuil.

Ricœur, P. (1990). Soi-même comme un autre [Oneself as another]. Paris, France: Éditions du Seuil. 
Ritchie, S., Tobin, K., Roth, W-M. \& Carambo, C. (2007). Transforming an academy through the enactment of collective curriculum leadership. Journal of Curriculum Studies, 39, 151-175.

Romano, C. (1998). L'événement et le monde [The event and the world]. Paris, France: Presses Universitaires de France.

Roth, W.-M. (2006). A dialectical materialist reading of the sign. Semiotica, 160, 141171.

Roth, W.-M. (2007). The ethico-moral nature of identity: Prolegomena to the development of third-generation cultural-historical activity theory. International Journal of Educational Research, 46, 83-93.

Roth, W.-M. (2008). The nature of scientific conceptions: A discursive psychological perspective. Educational Research Review, 3, 30-50.

Roth, W-.M. (2012). On the hunt for elusive "meanings." Cultural Studies of Science Education. DOI 10.1007/s11422-012-9392-4

Roth, W.-M., \& Radford, L. (2011). A cultural-historical perspective on mathematics teaching and learning. Rotterdam, The Netherlands: Sense Publishers.

Scherer, K.R. (1989). Vocal correlates of emotion. In H. L. Wagner \& A. S. R. Manstead (Eds.), Handbook of psychophysiology: Emotion and social behavior (pp. 165-97). London, UK: Wiley.

Selting, M., Auer, P., Barden, B., Bergmann, J., Couper-Kuhlen, E., Günthner, S., Meier, C., Quasthoff, U., Schlobinski, P., \& Uhmann, S. (1998). Gesprächsanalytisches Transkriptionssystem [Conversation analytic transcription system]. Linguistische Berichte, 173, 91-122.

Stith, I., \& Roth, W.-M. (2010). Teaching as mediation: The cogenerative dialogue and ethical understandings. Teaching and Teacher Education, 26, 363-370.

Suchman, L.A. (1987). Plans and situated actions: The problem of human-machine communication. Cambridge, UK: Cambridge University Press.

Thomas, E.L. (2004). Emmanuel Levinas: Ethics, justice and the human beyond being. New York, NY: Routledge.

von Glasersfeld, E. (1989). Facts and the self from a constructivist point of view. Poetics, 18, 435-448.

von Glasersfeld, E. (2009). Relativism, fascism, and the question of ethics in constructivism. Constructivist Foundations, 4, 117-120.

Vygotskij, L.S. (2002). Denken und Sprechen [Thinking and speaking]. Weinheim, Germany: Beltz Verlag.

Waldenfels, B. (2006). Grundmotive einer Phänomenologie des Fremden [Basic motives of a phenomenology of the foreign/strange]. Frankfurt/M, Germany: Suhrkamp.

Walshaw, M., \& Brown, T. (2011). Affective productions of mathematical experience. Educational Studies in Mathematics. doi: 10.1007/s10649-011-9370-X

Willis, P. (1977). Learning to labor: How working class lads get working class jobs. New York: Columbia University Press.

Wittgenstein, L. (1997). Philosophische Untersuchungen / Philosophical investigations. Oxford, England: Blackwell Publishers. (First published in 1953) 


\section{Appendix}

The transcription conventions are those of standard conversation analysis enhanced for the transcription of prosodic features (Selting et al., 1998). Unless modified, all words are written with small letters.

\begin{tabular}{|c|c|c|}
\hline Notation & Description & Example \\
\hline$(0.14)$ & Time without talk, in seconds & more ideas. (1.03) just \\
\hline$(($ turns $))$ & $\begin{array}{l}\text { Verbs and descriptions in double } \\
\text { parentheses are transcriber's } \\
\text { comments }\end{array}$ & ( (nods to Colby) ) \\
\hline : : & $\begin{array}{l}\text { Colons indicate lengthening of } \\
\text { phoneme, about } 1 / 10 \text { of a second per } \\
\text { colon }\end{array}$ & si::ze \\
\hline [ ] & $\begin{array}{l}\text { Square brackets in consecutive lines } \\
\text { indicate overlap }\end{array}$ & $\begin{array}{l}\mathrm{S}: \mathrm{s}[\text { ize }] \\
\mathrm{T}:[\text { colby }]\end{array}$ \\
\hline$<<f>\quad>$ & $\begin{array}{l}\text { Forte, words are uttered with louder } \\
\text { than normal speech volume }\end{array}$ & $<<$ f $>$ um $>$ \\
\hline$<<a l l>>$ & $\begin{array}{l}\text { Allegro, words are uttered with faster } \\
\text { than normal speed }\end{array}$ & $<<a l l>i$ donno $>$ \\
\hline ONE bert & $\begin{array}{l}\text { Capital letters indicate louder than } \\
\text { normal talk indicated in small letters. }\end{array}$ & no? okay, next ONE bert. \\
\hline $\mathrm{hh}$ & Noticeable out-breadth & \\
\hline,$- ? ;$ & $\begin{array}{l}\text { Punctuation is used to mark movement } \\
\text { of pitch (intonation) toward end of } \\
\text { utterance, flat, slightly and strongly } \\
\text { upward, and slightly and strongly } \\
\text { downward, respectively }\end{array}$ & $\begin{array}{l}\mathrm{T}: \text { so can we tell a shape by } \\
\text { its color? } \\
\mathrm{T}: \text { does it belong to another } \\
\text { group }(0.67) \text { o:r. }\end{array}$ \\
\hline$=$ & $\begin{array}{l}\text { Equal sign indicates that the phonemes } \\
\text { of different words are not clearly } \\
\text { separated }\end{array}$ & loo: : ks=similar \\
\hline v & $\begin{array}{l}\text { Diacritic indicates movement of pitch } \\
\text { within the word that follows - down-up }\end{array}$ & `buthh \\
\hline
\end{tabular}

